\title{
PENDAPAT MUHAMMAD SYAHRUR TENTANG POLIGAMI SERTA RELEVANSINYA BAGI RENCANA PERUBAHAN KHI
}

\author{
Firman Nurdiansyah
}

\author{
JL. Kendangsari no. 105-a RT 004 RW 004 Ds. Kendangsari Kec. \\ Tenggilis Mejoyo Surabaya. Email: fajrin08ff@gmail.com
}

\begin{abstract}
One of the topics that continues to reap controversy is polygamy. In the Islamic world, polygamy is interpreted differently through its main source, the Qur'an. One of the Muslim thinkers who contributed to the interpretation in this matter was Mubammad Syahrur who used the boundary theory in seeing the case of polygamy. By observing the context of the verse as a whole, Syabrur emphasized that polygamy can only be done if the second wife and so on are widows and have orphans. This paper is a study of the thoughts of Muhammad Syahrur through his monumental work. Al-Kitab Wa Al-Qur'an Qira'ah Mu'asirah and his other works. The thought of Mubammad Syahrur is described and then analyzed for its relevance to the amendment plan. Compilation of Islamic Law as a material law in deciding polygamy issues. The requirement for polygamy must be with widows with orphans as a valuable input for KHI, which has included the conditions for polygamy which have departed from the shortcomings and weaknesses of women, a requirement considered by feminist as a gender bias.
\end{abstract}

Keywords: Muhammad Syahrur, polygamy, and Compilation of Islamic Law (KHI)

Abstrak: salah satu topik yang terus menuai kontroversi adalah poligami.
Dalam dunia Islam, poligami ditafsirkan dengan cara berbeda-beda melalui
sumber utamanya, Alqur'an. Salah seorang pemikir muslim yang
memberikan sumbangan penafsiran dalam hal ini adalah Muhammad
Syahrur yang menggunakan teori batas dalam melihat kasus poligami.
Dengan memperhatikan konteks ayat secara keseluruhan, Syahrur
menegaskan, bahwa poligami boleh dilakukan hanya jika istri kedua dan
seterusnya adalah janda yang beranak yatim. Tulisan ini adalah kajian
terhadap pemikiran Muhammad Syahrur melalui karya monumentalnya
Al-Kitab Wa Al-Qur'an Qira'ah Mu'asirah beserta karya-karya Syahrur
lainnya. Pemikiran Muhammad Syahrur tersebut dideskripsikan kemudian
dianalisis relevansinya bagi rencana amandemen Kompilasi Hukum Islam
sebagai hukum materil dalam memutuskan persoalan-persoalan poligami.
Persyaratan poligami harus dengan janda beranak yatim dapat menjadi
masukan berharga bagi KHI yang selama ini mencantumkan syarat-syarat
poligami berangkat dari kekurangan-kekurangan dan kelemahan-

AL-HUKAMA

The Indonesian Journal of Islamic Family Law

Volume 08, Nomor 02, Desember 2018; ISSN:2089-7480 
kelemahan perempuan, persyaratan yang dinilai kalangan feminis bias gender.

Kata Kunci: Muhammad Syahrur, poligami, dan Kompilasi Hukum Islam (KHI)

\section{Pendahuluan}

Perkawinan merupakan suatu akad atau perjanjian untuk mengikat dua manusia, seorang laki-laki dan seorang perempuan untuk menghalalkan hubungan kelamin di antara keduanya dengan syarat dan rukun yang sudah ditentukan untuk mewujudkan kebahagiaan hidup keluarga, diliputi kasih sayang dan ketentraman dengan cara-cara yang diridloi oleh Allah.1 Alquran bahkan menyebut perkawinan dalam salah satu ayatnya sebagai mithaqan ghalidan (perjanjian yang kokoh).2

Salah satu bentuk perkawinan yang sering diperbincangankan dalam masyarakat muslim adalah poligami, karena selalu mengundang kontroversi. Poligami adalah ikatan perkawinan yang salah satu pihak (suami) mengawini beberapa (lebih dari satu orang istri) dalam waktu yang bersamaan.3 Kebalikan dari poligami ialah monogami, yaitu ikatan perkawinan yang hanya membolehkan suami mempunyai satu istri.

Berabad-abad sebelum Islam diwahyukan, masyarakat di berbagai belahan dunia telah mengenal dan mempraktekkan poligami. Poligami dipraktekkan secara luas di kalangan masyarakat Yunani, Persia dan Mesir kuno. Di jazirah Arab sendiri, jauh sebelum Islam, masyarakat telah mempraktekkan poligami, bahkan poligami tanpa terbatas. Sejumlah riwayat menceritakan, bahwa ratarata pemimpin suku ketika itu memiliki puluhan istri, bahkan tidak sedikit kepala suku mempunyai istri sampai ratusan.4

1Pasal 2 dan 3 Kompilasi Hukum Islam (Bandung: CV. Nuansa Aulia, 2012), 2.

2Musdah Mulia, Pandangan Islam Tentang Poligami (Jakarta: Lembaga Kajian Agama dan Jender dan Perserikatan solidaritas perempuan dan The Asia Foundation, 1999), 9.

3Rochayat Machali, Wacana Poligami di Indonesia (Bandung: PT. Mizan Pustaka, 2005), 46.

4 Siti Musdah Mulia, Islam Menggugat Poligami (Jakarta: PT. Gramedia Pustaka Utama, 2004), 45. 
Keberadaan poligami dalam Alquran hampir tidak ada lagi yang menolaknya. Seluruh ulama, baik klasik maupun modern, akan selalu berangkat dari kerangka dasar Alquran, jika berbicara tentang poligami. Meskipun setiap orang berangkat dari dasar pemikiran yang sama, namun kesimpulan yang dihasilkan cenderung beragam dan tidak jarang bertolak belakang. Tema poligami telah banyak dibahas oleh ulama sejak dahulu dan perdebatannya sampai sekarang. Hal ini dapat ditemukan terutama dalam kitab-kitab fikih dan tafsir.5

Islam memperbolehkan poligami dalam keadaan yang khusus dan dengan syarat-syarat berat. Seperti tercantum dalam QS. al-Nisa (4):3:

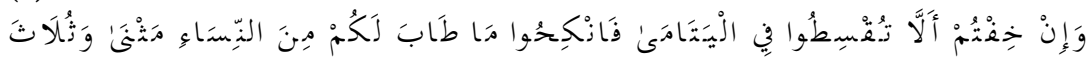

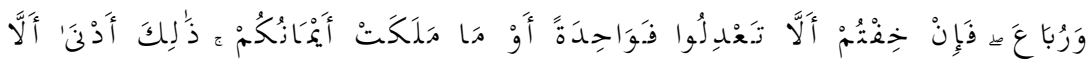

$$
\begin{aligned}
& \text { تَعَعُولُوا }
\end{aligned}
$$

Artinya : "Dan jika kamu takut tidak akan dapat berlaku adil terhadap (hak-hak) perempuan yatim (bila mana kamu mengawininya), maka kawinilah wanita-wanita (lain) yang kamu senangi; dua, tiga atau empat. Kemudian jika kamu takut tidak akan dapat berlaku adil, maka (kawinilah) seorang saja, atau budak-budak yang kamu miliki. Yang demikian itu adalah lebih dekat tidak berbuat aniaya".6

Ilustrasi ini memberikan sebuah pengertian, Islam membolehkan poligami, semata-mata hanya karena kemaslahatan yang dituntut oleh kondisi kehidupan. Allah yang menciptakan mahluk, Ia-lah yang lebih tahu tentang kemaslahatannya, bila Allah membolehkan hal tersebut pasti mempunyai hikmah. Demikian ungkap Sa'id al-Jandul.7

Kata "fankihu" yang terbentuk dari fi'il al-amr dalam ayat ini mengisyaratkan kewajiban (li al-wujub) atau hanya boleh (li al-ibahab)? Menurut jumhur ulama, sebagaimana diuraikan oleh Dahlan Idhami,

5Agus Sunaryo, "Poligami di Indonesia (Sebuah analisis Normatif-Sosiologis)", Portal Garuda, No.1, Vol.5 (Januari-Juni, 2010), 2.

6 Departemen Agama RI Mushaf Al Azhar Al Quran dan Terjemah..., 77.

7Said Abdul Aziz al Jandul, Wanita Di Bawah Naungan Islam, Diterjemahkan oleh Safil Halim (Jakarta: Firdaus, 1992), 71. 
poligami itu hukumnya ibahah (boleh) karena khithab (perintah) "fankibu ma taba lakum" (maka kawinilah wanita-wanita (lain) yang kamu senangi), adalah bersifat takhyir (pilihan) kepada mukallaf. 8 Sementara ablu al-Zahir menyebutkan, bahwa ayat ini menunjukkan kewajiban menikah bagi seorang muslim, karena al-amru li alwujub. Fakhru al-Razi menyatakan, dalam ayat ini Allah menetapkan, bahwa meninggalkan perkawinan dalam bentuk seperti ini (poligami) adalah lebih baik daripada mengerjakannya. Hal ini menunjukkan, bahwa ayat ini bukan menunjukkan kesunnahan menikah lebih dari satu, apalagi menunjukkan wajib.9

Perhatian penuh Islam terhadap poligami sebagaimana ayat di atas ini tidak semata-mata tanpa syarat. Islam menetapkannya dengan syarat, yaitu keadilan dan pembatasan jumlah. Keadilan menjadi syarat karena istri mempunyai hak untuk hidup dan bahagia. Adapun pembatasan jumlah menjadi syarat karena jika tidak dibatasi, maka keadilan akan sulit ditegakkan. Jika persyaratan tersebut tidak terpenuhi, maka tentu saja Islam melarangnya, dengan dua persyaratan itu, Islam menunujukkan perhatiannya pada hakhak perempuan, khususnya dalam masalah perkawinan. 10

Jika suami khawatir berbuat zalim dan tidak mampu memenuhi semua hak mereka, maka ia haram melakukan poligami. Bila ia hanya sanggup memenuhi hak-hak istri sebatas tiga orang, maka ia haram menikahi perempuan yang keempat. Bila ia hanya sanggup memenuhi hak-hak dua orang istri, maka ia haram menikahi istri untuk yang ketiganya, dan begitu seterusnya.

Jadi pada asasnya, poligami dibolehkan bagi seorang muslim dalam arti yang sebenarnya dan sanggup berlaku adil terhadap istriistrinya. Ia hanya boleh beristri seorang saja apabila ternyata ia tidak memiliki sifat-sifat tersebut.11

8Dahlan Idhamy, Azas-azas Figh Munakahat Hukum Keluarga Islam (Surabaya: AlIkhlas, 2002), 31.

9Ali Ash Shabuni, Tafsir Ayat al-Ahkam Minal Quran (Beirut: Maktabah al-Ghazali, 1981), Juz 1, 192.

10 Rodli Makmun, dkk, Poligami dalam Tafsir Muhammad Syahrur (Ponorogo: STAIN Ponorogo Press, 2009), 19.

11 Kamal Mukhtar, Asas-asas Hukum Islam Tentang Perkawinan (Jakarta: Bulan Bintang, 1993), 27. 
KHI (Kompilasi Hukum Islam) juga menyebutkan syarat dan batasan berpoligami seperti yang telah ditentukan dalam kitab-kitab fikih. Hal ini terlihat dalam ayat 1-3 pasal $55 \mathrm{KHI}$ yang berbunyi:12

1. Beristri lebih dari satu orang pada waktu bersamaan, terbatas hanya sampai empat istri.

2. Syarat utama beristri lebih dari seorang, suami harus mampu berlaku adil terhadap istri-istri dan anak-anaknya.

3. Apabila syarat utama yang disebut pada ayat (2) tidak mungkin dipenuhi, suami dilarang beristri dari seorang.

Latar belakang dari ketentuan poligami di atas diambil dari penafsiran kebanyakan ulama dalam kitab tafsir maupun kitab fikih yang dapat dikatakan sama sekali tidak ada perdebatan terhadap pemberlakuan poligami. Dalam kebanyakan kitab fikih disebutkan bahwa umat Islam sepakat mengenai kebolehan seorang laki-laki untuk menikahi perempuan maksimal empat orang. Kalimat ini langsung dikutip dalam pasal $55 \mathrm{KHI}$ persis sebagaimana dinyatakan dalam kitab-kitab salaf.13

Kemudian dijelaskan juga syarat-syarat formal poligami yang harus dijalani seorang suami sebagai perlindungan hukum bagi pelaku poligami, yakni disebutkkan dalam pasal 56 yang berbunyi:14

1. Suami yang hendak beristri lebih dari satu orang harus mendapatkan izin dari Pengadilan Agama.

2. Pengajuan permohonan Izin dimaksud pada ayat (1) dilakukan menurut pada tata cara sebagaimana diatur dalam BAB VIII Peraturan Pemeritah No.9 Tahun 1975.

3. Perkawinan yang dilakukan dengan istri kedua, ketiga atau keempat tanpa izin dari Pengadilan Agama, tidak mempunyai kekuatan hukum.

Selanjutnya dalam pasal 57 dijelaskan bahwa Pengadilan Agama hanya memberikan izin kepada suami yang akan beristri lebih dari satu orang apabila: 15

1. Istri tidak dapat menjalankan kewajiban sebagai istri;

12 Kompilasi Hukum Islam, (Bandung: CV. Nuansa Aulia, Cet III, 2007), 16.

13 Ratna Batar Munti dan Hindun Anisah, Posisi Perempuan dalam Hukum Islam di Indonesia (Jakarta: t.p., 2005) 103.

14 Kompilasi Hukum Islam..., 16-17.

15 Ibid. 
2. Istri mendapat cacat badan atau sakit yang tidak dapat disembuhkan;

3. Istri tidak dapat melahirkan keturunan.

Pasal 57 di atas merupakan syarat-syarat yang melekat pada seorang istri yaitu kondisi-kondisi nyata yang melingkupinya sehingga menjadi alasan logis bagi seorang suami untuk berpoligami. Kemudian pasal 58 yang berbunyi:16

1. Selain syarat utama yang disebut pada pasal 55 ayat (2) maka untuk memperoleh izin Pengadilan Agama, harus pula dipenuhi syarat-syarat yang ditentukan pada pasal 5 UndangUndang No.1 Tahun 1974 yaitu:

a. Adanya persetujuan istri

b. Adanya kepastian bahwa suami mampu menjamin keperluan hidup istri-istri dan anak-anak mereka.

2. Dengan tidak mengurangi ketentuan pasal 41 huruf $b$ Peraturan Pemerintah No. 9 Tahun 1975, persetujuan istri atau istri-istri dapat diberikan secara tertulis atau dengan lisan, tetapi sekalipun telah ada persetujuan tertulis, persetujuan ini dipertegas dengan persetujuan lisan istri pada sidang Pengadilan Agama.

3. Persetujuan dimaksud pada ayat (1) huruf a tidak diperlukan bagi seorang suami apabila istri atau istri-istrinya tidak mungkin dimintai persetujuannya dan tidak dapat menjadi pihak dalam perjanjian atau apabila tidak ada kabar dari istri atau istri-istrinya sekurang-kurangnya 2 tahun atau karena sebab lain yang perlu mendapat penilaian Hakim.

Pasal 58 di atas merupakan syarat-syarat formal yang diperankan seorang istri sebagai respon terhadap suami yang hendak memadu dirinya yang melibatkan instansi yang berwenang. Aturanaturan ini sebagai antisipasi untuk menjaga hubungan baik dalam keluarga setelah berjalannya keluarga poligami. Terakhir pasal 59 yang berbunyi:17

"Dalam hal istri tidak mau memberikan persetujuan, dan permohonan izin untuk beristri lebih dari satu orang

16 Ibid, 17-18.

17 Ibid, 18. 
berdasarkan atas salah satu alasan yang diatur dalam pasal 55 ayat (2) dan 57, Pengadilan Agama dapat menetapkan tentang pemberian izin setelah memeriksa dan mendengar istri yang bersangkutan di persidangan Pengadilan Agama, dan terhadap penetapan ini istri atau suami dapat mengajukan banding atau kasasi."

Kritik terhadap KHI dalam hal poligami ini dapat kita lihat pada pendapat seorang pemikir Islam yang juga termasuk anggota dari tim Counter Legal Draft KHI. Respon terhadap ketidakadilan dalam poligami di Indonesia sudah ada dalam wacana pemikiran Musdah Mulia. Dia lebih banyak berbicara tentang keadilan dalam KHI tentang permohonan poligami harus berdasarkan persetujuan istri. Namun terdapat pasal yang dianggapnya adalah hal yang ironis yang menyatakan: "Dalam hal istri tidak mau memberikan persetujuan izin untuk beristri lebih dari satu berdasarkan salah satu alasan yang diatur pasal 55 ayat (2) dan 57, Pengadilan agama dapat menetapkan tentang pemberian izin setelah memeriksa dan mendengar istri yang bersangkutan di sidang Pengadilan Agama, dan terhadap penetapan ini istri dapat mengajukkan banding atau kasasi”. Walaupun terdapat kalimat istri dapat banding atau kasasi, tapi hal ini tentulah menjadi beban psikologis bagi istri untuk mengajukan banding atau kasasi.18

Menurut Siti Musdah Mulia, semua alasan dalam UU Perkawinan hanya dilihat dari perspektif kepentingan suami dan sama sekali tidak mempertimbangkan kepentingan perempuan. Misalnya, andaikan suami tidak mampu menjalankan kewajibannya sebagai suami, atau suami cacat atau penyakit yang tidak bisa disembuhkan; atau suami dalam keadaan mandul. Ketentuan UU Perkawinan tentang poligami menurut Musdah Mulia jelas menunjukkan posisi subordinat perempuan di hadapan laki-laki.19

Hingga saat ini, KHI belum mengalami pembaharuan yang disesuaikan dengan konteks dinamika dan kultur masyarakat Indonesia saat ini. Hal ini karena KHI disusun tidak sepenuhnya dari

18 Wawan Gunawan dan Evie Shofia Inayati, Wacana Fikih Perempuan Dalam Perspektif Muhammadiyah, (Jakarta: Majelis Tarjih dan Pengembangan Pemikiran Islam PP Muhammadiyah Yogyakarta dan Universitas Muhammadiyah Prof. Hamka Jakarta, 2005), 202-203.

19 Ibid, 204. 
realitas empiris keindonesiaan, melainkan banyak memindahkan begitu saja apa saja yang ada dalam kitab-kitab fikih klasik.

Upaya untuk tetap menjawab tantangan modernitas dengan mensinergikan ajaran Islam (dalam Alquran dan Sunnah) juga dilakukan oleh Muhammad Syahrur, seorang pemikir Islam kontemporer yang menggunakan analisa linguistik dan saintifik dalam memahami ayat-ayat Alquran.20

Muhammad Syahrur berpendapat bahwa sesungguhnya Allah SW'T tidak hanya memperbolehkan poligami, akan tetapi sangat menganjurkannya, namun dengan tiga syarat yang harus dipenuhi. Pertama, berpoligami dalam waktu bersamaan (hidup bersama dalam ikatan perkawinan) terbatas hanya empat orang istri. Kedua, bahwa istri kedua, ketiga dan keempat adalah para janda yang memiliki anak yatim. Ketiga, harus terdapat rasa khawatir tidak dapat berbuat adil kepada anak-anak yatim. Sehingga perintah poligami akan menjadi gugur ketika tidak terdapat tiga syarat tersebut. Ketiga syarat ini berdasarkan pada struktur kaidah bahasa (hermeneutika) dalam firman-Nya dalam surat al-Nisa' ayat 3 yang telah disebutkan di muka.21

Berdasarkan latar belakang di atas, penulis bermaksud menganalisa dan menggali pendapat Muhammad Syahrur tentang poligami dalam hukum Islam untuk menemukan relevansinya bagi rencana perubahan KHI, Ada dua poin yang menjadi titik pijakan, yakni hukum poligami Islam dan poligami menurut pandangan Muhammad Syahrur. Penelitian-penelitian yang telah dilakukan memang banyak yang mengkaji dua hal tersebut. Namun demikian, menghubungkan keduanya pada ranah pembaharuan hukum, utamanya Kompilasi Hukum Islam di Indonesia, sejauh penelusuran penulis belum ada yang melakukan. Dalam penelitian yang dilakukan Ummi 'Atiyyah misalnya, dinyatakan bahwa, pada prinsipnya, Syahrur mengakui poligami menjadi bagian dari syari’at Islam, tetapi

20 Rodli Makmun, dkk, Poligami dalam Tafsir Muhammad Syahrur..., 2.

21Muhammad Syahrur, Nahw Usul Jadidah Li al-Fiqh al-Islami, Diterjemahkan Sahiron Syamsuddin dan Burhanudin (Yogyakarta: eLSAQ Press, 2004), 430. 
dalam penerapannya harus memperhatikan beberapa persyaratan, agar poligami itu membawa hikmah.22

Penelitian Maria Ulfah berjudul, Poligami Menurut Muhammad Syahrur dalam Pandangan Hukum Islam,23 menjelaskankan bahwa, dalam pandangan Islam, para ulama berbeda pendapat dalam memandang poligami. Pertama, kalangan yang berpendirian bahwa poligami merupakan salah satu sunnah Nabi. Kedua, ulama yang berpandangan bahwa poligami diperbolehkan dalam batas maksimal empat orang perempuan. Ketiga, ulama yang memperbolehkan poligami dengan syarat-syarat yang ketat. Muhammad Syahrur, salah satu ulama kontemporer yang memiliki teori tersendiri, yakni teori batas dalam memahami ayat tentang poligami. Muhammad Syahrur melihat poligami sangat terkait dengan kepentingan anak-anak yatim dan para janda. Ia menganalisa ayat poligami dengan teori batasnya, secara kuantitas dan kualitas. Batasan kuantitas dalam poligami, istri yang dinikahi minimal satu orang dan maksimal empat orang. Dan batas kualitasnya, bahwa yang dinikahi adalah janda yang mempunyai anak yatim.

Penelitian Nurul Aini berjudul: Perlindungan Anak Dalam Perkawinan Poligami Menurut Mubammad Syahrur Perspektif UndangUndang No. 23 Tabun 2002 Tentang Perlindungan Anak,24 menyimpulkan, bahwa Muhammad Syahrur menganalisis Surat alNisa' ayat 3 dengan menggunakan metode intra-tekstual dan sosiologis sekaligus. Menurutnya ayat 3 Surat al-Nisa' tidak bisa dilepaskan dari ayat 2 dan 6 yang berbicara mengenai pemeliharaan anak yatim. oleh karena itu, poligami juga harus dipahami dalam kerangka pemeliharaan anak yatim. Jika dilihat dari perspektif undang-undang no. 23 tahun 2002 tentang perlindungan anak sejalan dengan pendapat Muhammad Syahrur. Yakni, perlindungan

${ }_{22} \mathrm{Ummi}$ 'Atiyah, "Studi Komparatif tentang Syarat Istri Kedua Menurut Mubammad Syahrur dan Kompilasi Hukum Islam”'(Skripsi--UIN Maulana Malik Ibrahim, Malang, 2010).

23Maria Ulfah, "Poligami Menurut Muhammad Syahrur Dalam Pandangan Hukum Islam"(Skripsi--UIN Syarif Hidayatullah, Jakarta, 2011).

24Nurul Aini, "Perlindungan Anak Dalam Perkawinan Poligami Menurut Mubammad Syabrur Perspektif Undang-Undang No. 23 Tabun 2002 Tentang Perlindungan Anake" (Skripsi--UIN Maulana Malik Ibrahim, Malang, 2016) 
anak sebagai syarat seorang suami akan mengajukan permohonan poligami.

Dari semua kajian yang pernah dilakukan terhadap pemikiran Muhammad Syahrur tentang poligami, belum ada yang melihat relevansi pemikiran tersebut dengan rencara amandemen KHI. Kajian ini bermaksud mengambangkan kajian-kajian sebelumnya dengan melihat relevansi lebih jauh pemikiran Muhammad Syahrur bagi perubahan hukum keluarga Islam di Indonesia.

\section{Biografi Muhammad Syahrur}

Nama lengkap Syahrur adalah Muhammad Ibnu Deib Syahrur. Beliau adalah seorang pemikir muslim kontemporer yang lahir pada tanggal 11 Maret tahun 1938 di Damakus (Syiria).25 Buah perkawinan dari seorang ayah bernama Deib bin Deib Shahrur dan ibu bernama Siddiqah binti Salih Filyun.26 Dari istri tercintanya, Azizah, ia dikaruniai lima orang anak. Dari kelima anak tersebut masing-masing diberi nama Thariq, Lays, Basil, Ma'sun dan Rima dan ia juga mempunyai dua orang cucu yaitu Muhammad dan Kinan.27

Pada awalnya Syahrur tidak mempelajari ilmu-ilmu ke-Islam-an secara intensif, karena setelah menamatkan sekolah tingkat menengah di Abd al-Rahman al-Kawakibi, ia kemudian pergi ke Uni Soviet untuk belajar tehnik di Moskow. Setelah menyelesaikan S1, kemudian ia kembali ke Syiria dan pada tahun 1964 berhasil meraih gelar Diploma dalam teknik sipil serta bekerja sebagai dosen di Universitas Damaskus.28

Tahun 1965, Syahrur diangkat sebagai asisten dosen di Fakultas Teknik Sipil Universitas Damaskus. Kemudian oleh pihak Universitas, ia dikirim ke Irlandia untuk melanjutkan pendidikan Magister di Universitas College Dublin Irlandia dengan spesialisasi

25 Muhammad Syahrur, Al-Kitab wa Alquran : Qira'ah Mu'asirah (Damaskus: AlAhali li ath-Thiba'ah wa an-Nasyr wa at-Tauzi', 1990), 823.

26 Muhammad Syahrur, Dirasat Islamiyah Mu'ashirah fi al-Daulah wa al-Mujtama' (Damaskus: Al-Ahali li ath-Thiba'ah wa an-Nasyr wa at-Tauzi', 1994), vii.

27 Muhammad Syahrur, Nabwa Ushul Jadidah li al-Fiqh al-Islami: Figh al-Mar'ah (Damaskus: Al-Ahali li ath-Thiba'ah wa an-Nasyr wa at-Tauzi', 2000), 9.

28 Peter Clark, "The Shahrur Phenomenon: A Liberal Islamic Voice from Syria". Islam and Christian Moslem Relation, No. 3, Vol. 7, 
bidang Mekanika Tanah dan Teknik Fondasi.29 Pada tahun 1969, Syahrur meraih gelar Master of Science. Tiga tahun kemudian, 1972, ia dapat menyelesaikan program doktoralnya.30 Selain sebagai dosen, pada tahun 1982 sampai 1983, Syahrur dikirim kembali oleh pihak Universitas Damaskus untuk menjadi tenaga ahli pada al-Sa'ud Consult Arab Saudi serta bersama beberapa rekannya di Fakultas Teknik membuka Biro Konsultasi Teknik Dar al-Isytisyarat alHandasiyyah (En-Gineering Consultancy) di Damaskus.31

Meskipun Syahrur berlatarbelakang akademik bidang teknik, hal ini tidak berarti kosong sama sekali dari wacana pemikiran keIslam-an. Beberapa karya Muhammad Syahrur adalah sebagai berikut:

\section{Al-Kitab wa Alqur'an: Qira'ah Mu'asirah}

Penyusunan buku ini berlangsung sekitar dua puluh tahun dengan melewati tiga fase. Fase pertama antara tahun 979. Fase ini bermula saat Syahrur menempuh jenjang Magister dan Doktor dalam bidang teknik sipil Nation Uinversity of Ireland. Fase ini merupakan fase pengkajian dan peletakan dasar-dasar pemahaman Syahrur terhadap metodologi memahami konsep alZikr, al-iala dan al-Nubuwah, serta istilah-istilah dasar bagi al-Ziker. Dalam fase ini ia tidak terlalu produktif, hal ini disebabkan karena pengaruh pemikiran taqlid yang diwariskan yang ada dalam khazanah karya Islam lama dan modern. Dalam kurun waktu sepuluh tahun tersebut, Syahrur mendapati beberapa hal yang selama ini dianggap sebagai dasar Islam, namun ternyata bukan. Karena hal tersebut idak mampu menampilkan pandangan Islam yang murni dalam menghadapi tantangan abad ke-20.32

Fase kedua, antara tahun 1980-1986. Fase ini diawali dengan pertemuan Syahrur dengan Ja'far al-Bab, teman sejawatnya mengajar di Damaskus yang lulus doktornya di bidang ilmu bahasa atau linguistik (al-lisaniyyat) di Universitas Moskow tahun

29 Muhammad Syahrur, Al-Kitab wa Alquran : Qira'ah Mu'asirah..., 823.

30 Muhami Munir Muhammad Tahir al-Syawwaf, Tahafut al-Qira'ah al-Mu'asirah (Damaskus: al-Syawwa fi al-Nasyr, 1993), 11.

31 Ahmad Zaki Mubarok, Pendekatan Strukturalisme Linguistik dalam Tafsir Alquran Kontemporer "ala" Muhammad Syahrur, (Yogyakarta: el-SAQ Press, 2007), 139.

32 Muhammad Syahrur, Al-Kitab wa Alquran..., 46. 
1973. Ja'far inilah yange memperkenalkan Syahrur dengan pemikiran-pemikiran al-Farabi, Abu Ali al-Farisy dan muridnya, Ibnu Jinny dan Abd al-Qahir al-Jurjany. Dari pemikiran mereka itulah Syahrur memahami, bahwa lafadz mengikuti makna, bahwa bahasa Arab tidak mengenal sinonimitas (taraduf), bahwa nahwu dan balaghah merupakan dua ilmu yang saling berkaitan dan tidak dapat dipisahkan.33

Berangkat dari perspektif linguistik ini, Syahrur kemudian melakukan kajian intensif terhadap istilah-istilah pokok dalam Alqur'an, seperti al-Kitab, al-Qur'an, al-Furqan, al-Zikr, Umm alKitab, al-Lauh al-Mabfudz, al-Imam al-Mubin, al-hadis, absan al-hadis yang dikaji sampai tahun 1982. Setelah itu, Syahrur mulai mengkaji al-Inzal wa al-tanzil dan al-Ja’i. tahun 1984 sampai 1986, Syahrur bersama Dr. Ja'far mulai menulis pemikiran-pemikiran pokok hasil kajian intensifnya.34

Fase ketiga, antara tahun 1986-1990. Dalam fase ini Syahrur mulai menyusun pembahasan berdasarkan tema-tema tertentu. Tahun 1986-1987 ia berhasil menyelesaikan bab pertama buku alKitab wa al-Qur'an: Qira'ah Mu'asirah, yang merupakan masalahmasalah sulit. Bab-bab selanjutnya diselesaikan Syahrur sampai tahun 1990.35

2. Dirasat Islamiyah Mu'asirah fi al-Daulah wa al-Mujtama

Dalam buku ini Syahrur menguraikan tema-tema sosial politik yang terkait dengan persoalan masyarakat (al-Mujtama) dan Negara (al-daulab) dengan tetap berpijak pada tawaran metodologinya dalam memahami Alqur'an sebagaimana tertuang dalam buku pertamanya, secara konsisten Syahrur membangun konsep keluarga (al-Usrab), al-Ummah, al-Qaumiyyah, bangsa (alSyu'b), revolusi (al-syaurah), kebebasan (al-Hurriyyah), demokrasi dan al-Syura, Negara (al-daulab), tindakan otoriter (al-istibdad) dan jihad.36

3. Al-Islam wa al-Iman: Manzumah al-Qiyam

33 Ibid, 7.

34 Ibid.

35 Ibid, 48.

36 Muhammad Syahrur, Dirasat Islamiyah..., vi. 
Buku ini mencoba mengkaji ulang konsep-konsep klasik mengenai rukun Islam dan rukun Iman sebagai sesuatu yang paling mendasar dan penting dalam Islam, namun demikian melalui pelacakannya terhadap semua ayat Alqur'an yang berkaitan dengan persoalan tersebut, Syahrur menemukan konsep lain yang benar-benar berbeda dengan rumusan ulama terdahulu. Lima rukun Islam yang selama ini diyakini bersumber dari Alqur'an dan hadis, ternyata bagi Syahrur setelah mengelaborasi atas ayat-ayat Alqur'an hanya kesaksian bahwa tiada Tuhan selain Allah yang merupakan rukun Islam di samping dua rukun Islam lainnya, yaitu percaya kepada hari kiamat dan beramal salih. Sementara kesaksian bahwa nabi Muahammad SAW utusan Allah dan empat rukun Islam lainnya, sebagaimana keyakinan umat Islam selama ini, dipahami oleh Syahrur sebagai rukun Iman dan bukan rukun Islam.37 Buku ini juga membicarakan kebebasan manusia, perbudakan dan tentang ritual ibadah yang terangkum dalam konsep al-Ibad wa al-Abid. Hal lain yang menjadi kajian buku ini adalah hubungan anak dengan orang tua. 38

4. Nabwa Ushul al-Jadidah li al-Figh al-Islami: Figh al-Mar'ah

Sebagaimana dikatakan Syahrur sendiri, buku ini dapat dikatakan sebagai penyempurna terhadap kekurangankekurangan buku-bukunya terdahulu.39 Dalam buku ini Syahrur memaparkan metode penafsiran ayat-ayat hukum (bagian dari ayat mubkamat) yang berkaitan dengan masalah wasiat, pembagian harta warisan, kepemimpinan, poligami dan pakaian wanita. 40

Disamping karyanya dalam bentuk buku, pada tahun 1999, Syahrur menerbitkan sebuah buku saku yang berjudul Masyru' Mishaq al-'Amal al-Islami. buku saku ini ditulis sebagai jawaban Syahrur terhadap permintaan Forum Dialog Islam Internasional yang materi isinya tidak jauh berbeda dengan pokok-pokok pemikirannya yang telah tertuang dalam karya sebelumnya, $\mathrm{Al}$ -

37 Muhammad Syahrur, Al-Islam wa al-Iman..., 22.

38 Ibid, 23-24.

39 Muhammad Syahrur, Nahwa Ushul..., 15.

40 Ibid, 17-20. 
Islam wa al-Iman khususnya tentang perjanjian Islam (Mithaq alIslam).41

Selain dalam bentuk buku dan buku saku, Syahrur juga aktif menulis berbagai artikel yang dimuat dalam beberapa majalah, jurnal dalam bahasa Inggris dan bahasa Arab.42 Selain itu Syahrur sering mempresentasikan pokok-pokok pikirannya tentang Alqur'an kaitannya dengan masalah-masalah sosial dan politik, seperti hak-hak wanita, pluralism dalam banyak konferensi Internasional, antara lain MESA (Middle East Studies Associated) Conference tahun 1998 di Cichago.43

Melalui beberapa karya Syahrur di atas, apabila dibandingkan dengan pemikir muslim lain, Syahrur adalah sosok pemikir yang radikal. Ia membuang hampir seluruh peninggalan tradisi fiqh.44

\section{Poligami dalam Pandangan Muhammad Syahrur}

1. Pengertian Poligami Menurut Syahrur

Poligami dalam pandangan Muhammad Syahrur adalah seseorang laki-laki yang telah menikah dengan seorang wanita kemudian menikahi wanita janda yang memiliki anak yatim dalam waktu bersamaan.45 Poligami merupakan salah satu masalah besar yang dihadapi oleh perempuan Arab Islam secara khusus, dan yang dihadapi oleh Islam di depan dunia secara umum. Jika memahami ayat-ayat poligami dalam umm al-kitab dari perspektif ayat-ayat hududiah, seseorang akan mendapatkan pemahaman yang jauh lebih baik. Ayat-ayat tersebut mencakup setiap periode sejarah perkembangan manusia dan meliputi seluruh sisi kemuliaan manusia. Baik pada masa lampau maupun kontemporer.46

41 Achmad Syarqawi Ismail, Rekonstruksi Konsep Wabyu Mubammad Syahrur (Yogyakarta: eLSAQ Press, 2003), 50.

42 Muhyar Fanani, Figh Madani Konstruksi Hukum Islam di Dunia Modern (Yogyakarta: LKiS, 2010), 42.

43 Abdul Mustaqim dan Sahiron Syamsuddin, Studi Alquran Kontemporer..., 132.

44 Andreas Christman, dalam kata pengantar buku Muhammad Syahrur, Metodologi

Fiqh Islam Kontemporer, (Yogyakarta: eLSAQ Press, 2004), 18.

45 Muhammad Syahrur, Nabwa Ushul Jadidah..., 430.

46 Muhammad Syahrur, Al-Kitab wa Alquran : Qira'ah Mu'asirah..., 597. 
Dalam pandangan Muhammad Syahrur, Allah tidak hanya sekedar membolehkan poligami, tetapi sangat menganjurkan dengan syarat-syarat yang telah ditentukan.47 Menurutnya, dalam poligami terdapat sisi kemanusiaan dan social yang akan terselesaikan, yaitu manakala keadilan terhadap anak-anak yatim tidak dapat terlaksna dengan baik, dan akan terlaksana dengan cara menikahi ibu-ibu mereka yang menjanda.48 Dengan ketentuan tersebut Muhammad Syahrur berpendapat, bahwa calon istri yang boleh dipoligami oleh seorang suami harus perempuan janda yang memiliki anak yatim.

2. Dasar Hukum Poligami menurut Muhammad Syahrur

Menurut Syahrur,49 masalah poligami yang didasarkan pada teori bududnya dapat dipahami dari ayat;

a. QS. Al-Nisa' ayat 2

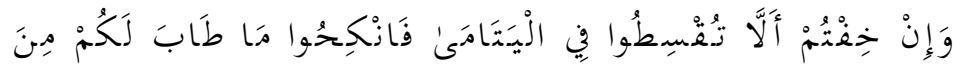

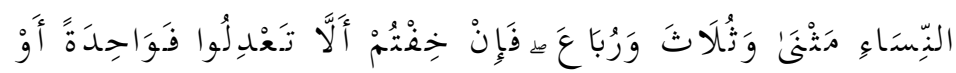

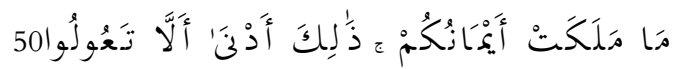

Syahrur dalam memahami ayat (al-Nisa' [4]: 3) poligami ini, mengaitkan dengan ayat yang sebelumnya, yaitu surat al-Nisa ${ }^{6}$ [4]: 2 tentang memelihara anak yatim51 dan membantu para janda yang suaminya gugur dalam peperangan. Oleh karenanya, menurut Syahrur, masalah poligami Allah meletakkan pada awal-awal surat al-Nisa', yakni ayat ke 3 dari surat al-Nisa'. Akan tetapi menurut Syahrur para mufassir dan ahli fiqih telah mengabaikan redaksi umum ayat tersebut dan mengabaikan keterkaitan erat antara poligami dengan para janda yang memiliki anak-anak yatim. 52

\footnotetext{
47 Muhammad Syahrur, nahwa Ushul Jadidah..., 303.

48 Ibid.

49 Muhammad Syahruur, Prinsip dan Dasar Hermeneutika..., 294.

50 Departemen Agama RI Mushaf Al Azhar Al Quran dan Terjemah...,77.

51 Muhammad Syahrur, nabwa Ushul Jadidah..., 302.

52 Ibid, 301.
} 
Syahrur berpendapat, bahwa ayat poligami ayat al-Nisa [ [4]: 3 berisi batas minimal dan batas maksimal yang hadir secara bersamaan. Menurutnya, ayat ini merupakan ayat bududiyyah.

b. QS. Al-Nisa' ayat 2

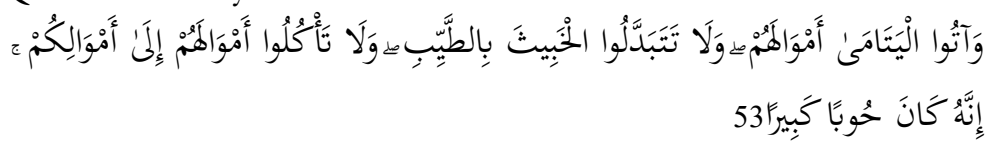

Ayat tersebut membicarakan hak-hak anak yatim yang dalam konteks ini, Allah memerintahkan kepada manusia agar memberikan harta benda anak-anak yatim dan tidak memakannya. Jadi antara poligami dan anak-anak yatim memiliki hubungan sebab-akibat (kausalitas). Hubungan kausalitas ini ditandai dengan lafaz " "و إن" (huruf shartiyah) yang terdapat pada surat al-Nisa' ayat 3, di mana lafar tersebut diatafkan kepada ayat sebelumya yaitu al-Nisa' ayat 2.54

Kata al-yatim dalam bahasa Arab dan dalam buku karya Muhammad Syahrur al-tanzil al-bakim berarti seorang anak yang belum mencapai umur baligh yang telah kehilangan ayahnya, sementara ibunya masih hidup. Anak yatim seperti ini yang ibunya boleh dipoligami.55

3. Syarat Poligami Menurut Muhammad Syahrur

Muhammad Syahrur dikenal dengan ke enam teori batasnya (budud), yaitu; a) Posisi batas minimal; b) Posisi batas maksimal; c) Posisi batas maksimal dan minimal bersama; d) Poisisi batas minimal dan maksimal bersamaan pada satu titik atau posisi lurus atau posisi penetapan hukum partikuler; e) posisi batas maksimum dengan satu titik mendekati garis lurus tanpa persentuhan; dan f) Posisi batas maksimum "positif" tidak boleh dilewati dan batas bawah "negatif" boleh dilewati.56

Adapun syarat-syarat poligami ini tergolong pada batas minimal dan batas maksimal hadir secara bersamaan namun tidak menyatu dalam satu garis. Pada ayat poligami terdapat batasan

53 Departemen Agama RI Mushaf Al Azhar Al Quran dan Terjemah...,77.

54 Muhammad Syahrur, Al-Kitab wa Alquran : Qira'ah Mu'asirah..., 598.

55 Muhammad Syahrur, Nahwa Ushul Jadidah..., 302.

56 Muhammad Syahruur, Prinsip dan Dasar Hermeneutika..., vi. 
maksimal dan minimal, baik dari segi kuantitas maupun kualitas. Masing-masing dijabarkan sebagai berikut:57

a. Batas-batas dalam sisi kuantitas

Surat al-Nisa' ayat 3 berbicara tentang pernikahan dengan lafaz "fankibu" yang kemudian mengawali jumlah istri dengan angka dua (mathna). Pada dataran realitas, seorang laki-laki tidak dapat dikatakan "menikahi dirinya sendiri" atau menikahi "setengah orang perempuan", maka batasan minimal istri adalah satu orang perempuan, dan batas maksimalnya adalah empat orang perempuan. Proses peningkatan jumlah ini diawali dari dua, tiga dan terakhir empat dalam hitungan bulat karena manusia tidak dapat dihitung dengan angka pecahan. Penyebutan satu persatu jumlah perempuan dalam redaksi mathna wa thulatha wa rua' harus dipahami sebagai penyebutan bilangan bulat secara berurutan, sehingga tidak dapat dipahami sebagai "dua+tiga+empat" yang berjumlah Sembilan.

b. Batas-batas dalam sisi kualitas

Perempuan seperti apakah yang dimaksud oleh ayat ini (yang diperbolehkan untuk dipoligami)? Apakah ayat ini menyebutkan terma "perempuan" mencakup semua kategori perempuan tanpa pengecualian?

Yang dimaksud di sini adalah janda (thayyib). Karena ayat yang dimaksud di atas memakai bentuk kalimat shartiyah, maka bias dipahami sebagai "fankibu ma taba lakum min al-nisa mathna wa thulatha wa ruba'..." dengan syarat kalau "wa in khiftum an la tuqsitu fi al-yatama..." dengan demikian, maka syarat-syarat istri kedua dan berikutnya adalah harus janda yang mempunyai anak-anak yatim dan mau menerima anak-anak yatim tersebut.

Secara tekstual, generalisasi pemahaman terhadap ayat ini tidak dapat dibenarkan. Petikan ayat "wa in khiftum an la tuqsitu fi al-yatama" tidak dapat dipisahkan dari petikan ayat selanjutnya, "fankibu ma taba lakum minan nisa' mathna wa thulatha wa ruba'...". Dalam konteks ini, Tuhan menyebutkan pembolehan poligami dimulai dari istri kedua, ketiga dan 
keempat dan tidak menyebutkan istri yang pertama. Sehingga secara kualitatif istri pertama tidak termasuk kategori perempuan yang dipoligami. Dapat difahami dari teks, bahwa perempuan yang dimaksud adalah ibu Janda yang memiliki anak yatim. Jadi maksudnya adalah bukannya menikahi anak yatim tersebut yang masih kecil, akan tetapi menikahi ibunya yang janda yang memiliki anak yatim. Sebaliknya selamanya tidak akan boleh bila seorang laki-laki menikahi janda yang memiliki anak, namun hanya mengambil ibunya tanpa menyertakan anaknya karena hal ini telah melanggar dari budud Allah. Hukum Islam selamanya tidak akan membolehkan demikian. 58

Menurut Syahrur, ibunya pastilah seorang janda yang relatif masih muda. Syahrur memahami bahwa pembolehan menikahi perempuan kedua, ketiga, dan keempat adalah dengan syarat bahwa wanita tersebut memiliki anak-anak yang masih kecil. Inilah pesan keseluruham dari pembolehan ini.59

Menurut Syahrur, sesungguhnya Allah tidak hanya sekedar memperbolehkan poligami, akan tetapi Allah sangat menganjurkannya, namun dengan dua syarat harus dipenuhi. Jika syarat tersebut tidak terpenuhi maka perintah poligami men-jadi gugur. Syarat-syaratnya adalah: pertama, istri kedua, ketiga dan keempat harus janda yang memiliki anak yatim, sebagaimana diatas. Kedua, harus terdapat rasa khawatir tidak dapat berbuat adil kepada anak-anak yatim.60

Lebih jauh lagi Syahrur berpendapat, bahwa kata tuqshithu yang dipakai pada permulaan surat al-Nisa' ayat 3 dengan kata tadilu pada akhir ayat yang sama memiliki konsekuensi makna yang berbeda. Namun para mufassir kebanyakan memaknai tuqsitu maupun ta'dilu dengan makna dan pemahan yang sama artinya adil. Menurut Syahrur, dalam lafaz wa in khiftum alla tuqshitu, tuqshitu disini adil hanya dalam satu ujung saja. Karena Allah berbicara masalah keadailan untuk anak-anak yatim

58 Ibid, 600.

59 Ibid, 295.

60 Muhammad Syahrur, Nabw Usul Jadidah..., 303. 
"jika kamu tidak bisa berbuat adil terhadap anak-anak yatim (adil terhadap satu ujung saja atau bukan pihak lain, yakni pihak anak-anak yatim)". Sedangkan ketika Allah berfirman tentang kehawatiran kita tidak bisa berbuat adil terhadap anak kita sendiri, satu pihak, dan anak yatim bawaan istri, pihak yang lain, Allah menggunakan kata 'adala, ...wa in khiftum alla ta'dilu fawabidatan....61

Dengan demikian, maka Syahrur ingin mengembalikan aspek kemanusiaan dalam kasus poligami, yakni terpeliharanya anak yatim. Akan tetapi, karena ayat ini bersifat bududiyyah maka Syahrur berpendapat, bahwa seorang hakim boleh membangun berbagai kemungkinan dalam menetapkan hukum seputar poligami, tentunya dengan memperhatikan kecendrungan sosial objektifnya. Misalnya, ketika jumlah lakilaki banyak berkurang akibat menjadi korban perang, maka seorang penetap hukum mungkin membolehkan atau mengizinkan seorang suami menikahi dua sampai empat perempuan janda yang tidak memiliki anak. Akan tetapi, selamanya tidak akan boleh bila seorang laki-laki menikahi janda yang memiliki anak, namun hanya mengambil ibunya tanpa menyertakan anaknya karena hal ini telah keluar dari budud Allah.62

\section{Analisis Hukum Islam Terhadap Pendapat Muhammad Syahrur Tentang Syarat Istri Kedua dan Seterusnya Harus Janda Yang Memiliki Anak}

Berdasarkan hasil pencarian data penulis terhadap pendapat Syahrur tentang syarat istri kedua dan seterusnya, penulis telah mendapatkan data berupa pandangan Muhammad Syahrur terhadap ayat poligami dengan teori bududnya.

Dari uraian penjelasan serta keterangan dari beberapa buku Muhammad Syahrur, maka beberapa penjelasan itu dapat dipetakan sebagai berikut:

61 Ibid, 301-305.

62 Muhammad Syahrur, al-Kitab wa al-Qur"an: Qira"ah Mu"asirah..., 600. 
1. Pada ayat poligami terdapat batasan maksimal dan minimal dari segi kuantitas.63

Surat al-Nisa' ayat 3 berbicara tentang pernikahan dengan lafaz. "fankibu" yang kemudian mengawali jumlah istri dengan angka dua (mathna). Pada dataran realitas, seorang laki-laki tidak dapat dikatakan "menikahi dirinya sendiri" atau menikahi "setengah orang perempuan", maka batasan minimal istri adalah satu orang perempuan, dan batas maksimalnya adalah empat orang perempuan. Proses peningkatan jumlah ini diawali dari dua, tiga dan terakhir empat dalam hitungan bulat karena manusia tidak dapat dihitung dengan angka pecahan. Penyebutan satu persatu jumlah perempuan dalam redaksi mathna wa thulatha wa rua' harus dipahami sebagai penyebutan bilangan bulat secara berurutan, sehingga tidak dapat dipahami sebagai "dua+tiga+empat" yang berjumlah Sembilan.

2. Pada ayat poligami terdapat batasan maksimal dan minimal dari segi kualitas.

Perempuan yang dimaksud oleh ayat poligami adalah janda (thayyib). Karena ayat di atas memakai bentuk kalimat shartiyah, maka bisa dipahami sebagai "fankihu ma taba lakum min al-nisa mathna wa thulatha wa ruba'..." dengan syarat kalau "wa in kbiftum an la tuqsitu fi al-yatama..." dengan demikian, maka syarat-syarat istri kedua dan berikutnya adalah harus janda yang mempunyai anak-anak yatim dan mau menerima anak-anak yatim tersebut. Secara tekstual, generalisasi pemahaman terhadap ayat ini tidak dapat dibenarkan. Petikan ayat "wa in kbiftum an la tuqsitu fi alyatama "tidak dapat dipisahkan dari petikan ayat selanjutnya, "fankibu ma taba lakum minan nisa' mathna wa thulatha wa ruba'...". Dalam konteks ini, Tuhan menyebutkan pembolehan poligami dimulai dari istri kedua, ketiga dan keempat dan tidak menyebutkan istri yang pertama. Sehingga secara kualitatif istri pertama tidak termasuk kategori perempuan yang dipoligami.64

Penafsiran seperti di atas tidak kita dapatkan pada pendapat jumhur ulama, terlebih tokoh fiqh klasik. Semua

63 Ibid, 235-236.

64 Ibid, 600. 
tokoh fiqh baik dari kalangan tokoh klasik maupun tokoh modern sepakat bahwa adil adalah persyaratan yang dituntut oleh Alqur'an untuk mensahkan poligami. Sedangkan mengenai hukumnya, meskipun menggunakan dasar (dalil) yang berbeda, para tokoh figh tradisional mengakui, bahwa poligami boleh hukumnya, bukan dianjurkan (Sunnah), apalagi wajib (amr/perintah). Sedangkan tokoh Muslim kontemporer cenderung melarang atau mengharamkan, tetapi masih membuka kemungkinan untuk membuka kebolehannya. Poligami diumpamakan seperti jalan darurat yang tidak semua orang sanggup melaluinya karena persyaratan adil yang begitu berat yang harus dilalui. Hanya orang tertentu saja yang bisa melaluinya.

Tokoh tradisional membolehkan poligami karena persyaratan adil yang dituntut Alqur'an adalah keadilan yang bersifat fisik, sedangkan tokoh kontemporer cenderung melarang poligami dengan alasan bahwa keadilan yang dituntut Alqur'an adalah keadilan hati, sedangkan hati sulit sekali berbuat adil. Dan Allah sudah memperingatkan hal ini dalam QS. an-Nisa :129.

Muhammad Syahrur berpendapat seperti di atas karena memahami suatu nash harus memperhatikan nash sebelum dan sesudahnya yang relevan dengan permasalahan (munasabah ayat). Dalam munasababnya Muhammad Syahrur menemukan syarat istri kedua dan seterusnya adalah harus perempuan janda yang memiliki anak.

Pendapat Syahrur berbeda jauh dengan pendapat jumbur ulama, namun kita tidak boleh menyalahkan, karena Syahrur tetap menggunakan dasar yang sama dengan jumbur ulama dalam penggalian hukumnya, hanya saja dengan pendekatan yang berbeda, yakni pendekatan munasabah ayat.

\section{Relevansi Pendapat Muhammad Syahrur Tentang Poligami dengan Rencana Perubahan KHI}

Tujuan perkawinan yang paling asasi adalah sakinah mawaddah wa rahmah sebagaimana tercantum juga di dalam KHI. Tapi dengan adanya poligami, tujuan perkawinan yang dicita-citakan tersebut sulit atau bahkan tidak tercapai. Ada anggapan, hal itu terjadi justru 
karena Islam telah mengabsahkan suami untuk beristri lebih dari seorang.

KHI hingga saat ini belum mengalami pembaharuan yang disesuaikan dengan konteks dinamika dan kultur masyarakat Indonesia ini. Hal ini karena KHI disusun tidak sepenuhnya dari realitas empiris keindonesiaan, melainkan banyak memindahkan begitu saja apa saja yang ada dalam tafsir-tafsir keagamaan klasik.

Kritik Musdah Mulia tentang persyaratan poligami dalam KHI perlu diperhatikan. Menurut Siti Musdah Mulia semua alasan dalam UU Perkawinan (termasuk di dalamnya KHI) hanya dilihat dari perspektif kepentingan suami dan sama sekali tidak mempertimbangkan kepentingan perempuan. Misalnya, andaikan tidak mampu menjalankan kewajibannya sebagai suami, atau suami cacat atau penyakit yang tidak bisa disembuhkan; atau suami dalam keadaan mandul. Ketentuan UU Perkawinan tentang poligami menurut Musdah Mulia jelas menunjukkan posisis subordinat perempuan dihadapan laki-laki.

Penafsiran Muhammad Syahrur dalam hal ini dapat dijadikan alternatif ketentuan yang lebih berpihak kepada kepentingan perempuan, anak-anak dan persoalan sosial. Berbeda dengan KHI yang hanya melihat poligami dari sisi kepentingan laki-laki sehingga yang dijadikan syarat melakukan poligami adalah kelemahankelemahan dan kekurangan-kekurangan istri. Dengan menetapkan syarat menikahi janda-janda dan anak-anak yatim yang terlantar, maka misi poligami dalam mengatasi problem sosial akan terlihat. Persyaratan utama yang diwajabkan Syahrur ini, menurut penulis lebih sesuai dengan spirit Alqur'an yang terlebih dahulu berbicara tentang anak yatim sebelum berbicara tentang poligami. Sedangkan persyaratan yang ditetapkan dalam KHI justru mewadahi nafsu lakilaki untuk terus menambah istri dengan alasan-alasan kelemahan istri. Persyaratan tersebut justru bertentangan dengan prinsip membangun keluarga bahagia dalam definisi perkawinan.

Ketidakberpihakan KHI terhadap perempuan juga terlihat dari bagaimana KHI mengabaikan ketidaksetujuan perempuan untuk dipoligami. Meskipun persetujuan istri dijadikan syarat dalam pemberian izin poligami, tetapi hakim dapat mengabaikan pendapat 
istri dengan membuat putusan yang berbeda. Hal ini terbaca dari pasal 58 ayat (3) KHI:

"Dalam hal istri tidak mau memberikan persetujuan izin untuk beristri lebih dari satu berdasarkan salah satu alasan yang diatur pasal 55 ayat (2) dan 57, Pengadilan agama dapat menetapkan tentang pemberian izin setelah memeriksa dan mendengar istri yang bersangkutan di sidang Pengadilan Agama, dan terhadap penetapan ini istri dapat mengajukkan banding atau kasasi”.

Spirit Alqur'an tentang keadilan sosial, menurut penulis perlu ditagaskan dalam pembuatan pasal-pasal tentang syarat-syarat poligami. Melalui penafsiran Muhammad Syahrur tentang poligami ini, KHI dapat dibenahi agar pasal-pasal yang dibuat bukan malah menegaskan hal yang sebaliknya, bertentangan dengan Alqur'an, melainkan mengakomodasi problematika sosial dan menciptakan keadilan di antara perempuan dan anak-anak.

\section{Penutup}

Dalam menafsirkan ayat-ayat Alqur'an tentang poligami, Muhammad Syahrur membaca ayat-ayat tersebut secara utuh, yaitu dengan mengaitkan satu ayat dengan ayat sebelum dan sesudahnya sehingga dipahami maksud yang sebenarnya. Poligami dipahami Muahammad Syahrur dengan melihat ayat sebelumnya yang berbicara tentang anak yatim sehingga ia menyimpulkan bahwa wanita yang boleh menjadi istri kedua, ketiga dan keempat adalah janda yang beranak yatim. Keadilan harus dilakukan, baik terhadap istri-istri dan terutama terhadap anak-anak kandung dan anak-anak tiri yang dibawa istri.

Pendapat Muhammad Syahrur ini menjadi kritik pedas buat KHI yang selama ini mendasarkan izin poligami pada kelemahankelemahan dan kekurangan-kekurangan istri. KHI perlu diarahkan untuk menampakkan visi keadilan sosial dalam syariat poligami melalui penetapan syarat-syarat yang adil buat perempuan, anakanak yatim dan masyarakat secara keseluruhan.

\section{Daftar Pustaka}

Abdul Mustaqim dan Sahiron Syamsuddin, Studi Alquran Kontemporer, Wacana Baru Berbagai Metodologi Tafsir, Yogyakarta: Tiara Wacana, 2002. 
Achmad Syarqawi Ismail. Rekonstruksi Konsep Wabyu Mubammad Syahrur, Yogyakarta: eLSAQ Press, 2003.

Agus Sunaryo. "Poligami di Indonesia (Sebuah analisis NormatifSosiologis)", Portal Garuda, No.1, Vol.5, Januari-Juni, 2010.

Ahmad Zaki Mubarok. Pendekatan Strukturalisme Linguistik dalam Tafsir Alquran Kontemporer "ala" Mubammad Syabrur, Yogyakarta: el-SAQ Press, 2007.

Ali Ash Shabuni, Tafsir Ayat al-Abkam Minal Quran, Beirut: Maktabah al-Ghazali, 1981, Juz 1.

Andreas Christman, dalam kata pengantar buku Muhammad Syahrur, Metodologi Figh Islam Kontemporer, Yogyakarta: eLSAQ Press, 2004.

Dahlan Idhamy. Azas-azas Fiqh Munakahat Hukum Keluarga Islam, Surabaya: Al-Ikhlas, 2002.

Kamal Mukhtar. Asas-asas Hukum Islam Tentang Perkawinan, Jakarta: Bulan Bintang, 1993.

Maria Ulfah. "Poligami Menurut Muhammad Syahrur Dalam Pandangan Hukum Islam", Skripsi--UIN Syarif Hidayatullah, Jakarta, 2011.

Muhami Munir Muhammad Tahir al-Syawwaf. Tahafut al-Qira'ah alMu'asirah Damaskus: al-Syawwa fi al-Nasyr, 1993.

Muhammad Syahrur. Dirasat Islamiyah Mu'ashirah fi al-Daulah wa alMujtama', Damaskus: Al-Ahali li ath-Thiba'ah wa an-Nasyr wa at-Tauzi', 1994.

-. Al-Kitab wa Alquran : Qira'ah Mu'asirah, Damaskus: Al-Ahali li ath-Thiba'ah wa an-Nasyr wa at-Tauzi', 1990.

-. Nabw Usul Jadidah Li al-Fiqh al-Islami, Diterjemahkan Sahiron Syamsuddin dan Burhanudin, Yogyakarta: eLSAQ Press.

-. Nahwa Ushul Jadidah li al-Fiqh al-Islami: Fiqh al-Mar'ah, Damaskus: Al-Ahali li ath-Thiba'ah wa an-Nasyr wa atTauzi', 2000.

Muhyar Fanani. Fiqh Madani Konstruksi Hukum Islam di Dunia Modern, Yogyakarta: LKiS, 2010.

Musdah Mulia. Pandangan Islam Tentang Poligami, Jakarta: Lembaga Kajian Agama dan Jender dan Perserikatan solidaritas perempuan dan The Asia Foundation, 1999. 
Firman Nurdiansyah: Pendapat Muhammad Syahrur......

Nurul Aini. "Perlindungan Anak Dalam Perkawinan Poligami Menurut Mubammad Syahrur Perspektif Undang-Undang No. 23 Tabun 2002 Tentang Perlindungan Anak", Skripsi--UIN Maulana Malik Ibrahim, Malang, 2016.

Peter Clark. "The Shahrur Phenomenon: A Liberal Islamic Voice from Syria". Islam and Christian Moslem Relation, No. 3, Vol. 7.

Ratna Batar Munti dan Hindun Anisah. Posisi Perempuan Dalam Hukum Islam di Indonesia, Jakarta: t.p., 2005.

Rochayat Machali. Wacana Poligami Di Indonesia, Bandung: PT. Mizan Pustaka, 2005.

Rodli Makmun. dkk. Poligami dalam Tafsir Mubammad Syahrur, Ponorogo: STAIN Ponorogo Press, 2009..

Said Abdul Aziz al Jandul. Wanita Di Bawah Naungan Islam, Diterjemahkan oleh Safil Halim, Jakarta: Firdaus, 1992.

Siti Musdah Mulia. Islam Menggugat Poligami, Jakarta: PT. Gramedia Pustaka Utama, 2004.

Ummi 'Atiyah. "Studi Komparatif tentang Syarat Istri Kedua Menurut Muhammad Syahrur dan Kompilasi Hukum Islam", Skripsi--UIN Maulana Malik Ibrahim, Malang, 2010.

Wawan Gunawan dan Evie Shofia Inayati. Wacana Fikib Perempuan Dalam Perspektif Muhammadiyah, Jakarta: Majelis Tarjih dan Pengembangan Pemikiran Islam PP Muhammadiyah Yogyakarta dan Universitas Muhammadiyah Prof. Hamka Jakarta, 2005.

Kompilasi Hukum Islam, Bandung: CV. Nuansa Aulia, Cet III, 2007. 